\title{
ブドウ球菌のグルタミン酸呼吸に対する 諸種阻害剂态び抗生物質の作用
}

\author{
岡山大学医学部微生物学校室（指村上栄敏授） \\ 矢 部 芳 郎 \\ 秋田和男 \\ 秋田悅示
}

[昭和 32 年 9 月 12 日受稿]

\section{粕害}

グルタミン酸がフドウ球菌の生理乃至代謝 面飞於て，極めて重要な役割を果す事が報告 されているい2．このグルタミン酸を基質と した場合のブド球菌の呼吸に对する諸種阻 害剂及び抗生物質の作用をしらべここれ等の 物質の作用機序と同時にブドウ球菌細胞の生 理的機構の一端を窥つた。

\section{実験方法及ひ材料}

使用菌：教室保存のブドウ球菌 Staphylococcus citreus 及び aureus (寺島).

菌調製方法: 前記フドウ球菌を普通寒天平 板上江 $37^{\circ} \mathrm{C}, 18$ 時閏坮羡後, 採取し, $\mathrm{M} / 50$
燐酸緩衝液で 2 回洗湺し，蒸溜水に浮游した。 菌量は島津光電比濁法炕より調製した。

呼吸測定方法：ワールフルルク検圧計を用い， $37.5^{\circ} \mathrm{C}$ 飞於て常法飞従つて測定を行つた。

\section{実 験 結 果}

\section{第一節 生菌の呼吸に対する諸種 阻害剂の作用}

1. チオニンの作用. 酸化還元反心醉菜系 に於てメチレンブルー若しくはキオニンが電 子運搬系の代りに嘚々使用される事は采知の 事実である。然るに，チォニンを生菌に添加 した場合，表 1 にみる如く，チオニンは菌の 呼吸を阻害した。

表 1 フドウ球菌の呼吸とチオニン

\begin{tabular}{|c|c|c|c|c|c|c|c|c|}
\hline & \multicolumn{4}{|c|}{ Staph. citreus } & \multicolumn{4}{|c|}{ Staph，aureus（寺島） } \\
\hline & 酸 & 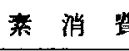 & 費 量 & チオニン & 酸 & 菜消 & 費 量 & Fオ二ン \\
\hline & 全量 $\mu 1$ & 補正值 $\mu 1$ & 1 阻㕩率\% & 着色圆 & 全孟 $\mu 1$ & 補正值 $\mu$ & 1 阻椠率的 & 著色度 \\
\hline ナチォニン & $\begin{array}{r}11 \\
7\end{array}$ & & & 世 & $\begin{array}{r}10 \\
7\end{array}$ & & & H \\
\hline 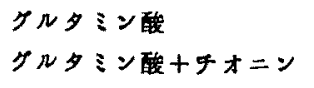 & $\begin{array}{l}64 \\
26\end{array}$ & $\begin{array}{l}53 \\
19\end{array}$ & 64 & \pm & $\begin{array}{r}159 \\
17\end{array}$ & $\begin{array}{r}149 \\
10\end{array}$ & 93 & H \\
\hline $\begin{array}{l}\text { タコーース } \\
\text { タルコース+キォニン }\end{array}$ & $\begin{array}{l}35 \\
22\end{array}$ & $\begin{array}{l}24 \\
15\end{array}$ & 38 & \pm & $\begin{array}{r}102 \\
50\end{array}$ & $\begin{array}{l}92 \\
43\end{array}$ & 53 & \pm \\
\hline
\end{tabular}

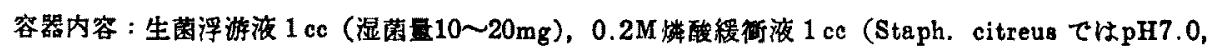

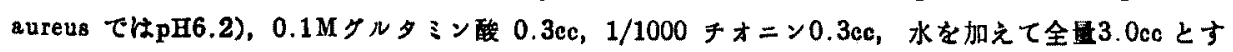
万. 気相 : 空気。 $37.5 。 C, 60$ 分。 
又チオニンを添加して呼吸を行わせた後迠 沈して得た菌は紫色染つて椱り, 呼吸阻害 の強いるの程より強く染つていた，その阻害 作用は、クルタミン酸を基質とした場合によ り強く，又, Staph. aureus (寺島) 飞対して, Staph. citreus 飞対するよりむ強かつた，尚 Staph. anreus 飞於てはクルタミン酸呼吸の*
*至適 $\mathrm{pH}$ は6.2K存在するため3), 実験はすべ $\tau \mathrm{pH} 6.2$ K於て行つた.

2. シャンカリの作用. シャンカリは呼 吸醇素系の中，チトクロム系を阻害する事は よく知られている。フドウ球菌に於ても，シ ヤンは強く呼吸を阻害した(表 2 )。

表 2 ブトウウ球菌の呼吸飞対する $\mathrm{KCN}$ 及びチオニンの作用

\begin{tabular}{|c|c|c|c|c|c|c|c|c|c|}
\hline & & & & 酸 & 消 & 費 & 量 & $\mu 1$ & \\
\hline & & \multicolumn{4}{|c|}{ Staph. citreus } & \multicolumn{4}{|c|}{ Staph. aureus (寺島) } \\
\hline & & 全 & 量 & 補 正值 & 阻害率名 & 全 & 量 & 補 正值 & 阻害事\% \\
\hline - & & & 50 & & & & 16 & & \\
\hline- & $+\mathrm{KCN}$ & & 19 & & & & 14 & & \\
\hline - & $+\mathrm{KCN}+$ チオニン & & 61 & & & & 13 & & \\
\hline \multicolumn{2}{|c|}{ クルタミン醚 } & & 172 & 122 & 0 & & 228 & 212 & 0 \\
\hline \multicolumn{2}{|c|}{ クルタミン酸 $+\mathrm{KCN}$} & & 21 & 2 & 98 & & 23 & 9 & 96 \\
\hline \multicolumn{2}{|c|}{ 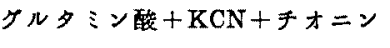 } & & 64 & 3 & 98 & & 22 & 9 & 96 \\
\hline
\end{tabular}

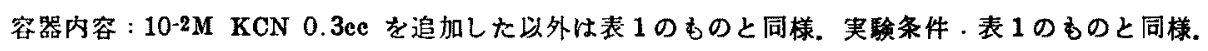

然しその阻害作用はチオニン添玑により恢

復されなかつた。
3. 窒化ソータの作用. 窒化ソーダ強 く呼吸を阻害した（表 3 ). Staph.- citreus

表 3 プドウ球菌の呼吸に対する $\mathrm{NaN}_{3}$ 及びチオニン

\begin{tabular}{|c|c|c|c|c|c|c|c|c|c|}
\hline & & & & 酸 & 消 & 費 & 量 & $\mu \mathbf{l}$ & \\
\hline & & \multicolumn{4}{|c|}{ Staph. citreur } & \multicolumn{4}{|c|}{ Staph. aureus (寺島) } \\
\hline & & 全 & 量 & 補正的 & 阻害率名 & 全 & 量 & 補 正 值 & 阻害率名 \\
\hline - & & & 50 & & & & 21 & & \\
\hline- & $+\mathrm{NaN}_{3}$ & & 46 & & & & 12 & & \\
\hline- & $+\mathrm{NaN}_{3}+$ チニン & & 51 & & & & 11 & & \\
\hline \multicolumn{2}{|c|}{ クルタミン酸+ } & & 172 & 122 & 0 & & 170 & 149 & 0 \\
\hline \multicolumn{2}{|c|}{ クルタミン政 $+\mathrm{NaN}_{3}$} & & 46 & 0 & 100 & & 21 & 9 & 94 \\
\hline \multicolumn{2}{|c|}{ クルタミン酸 $+\mathrm{NaN}_{3}$ チオン } & & 73 & 22 & 82 & & 20 & 9 & 94 \\
\hline
\end{tabular}

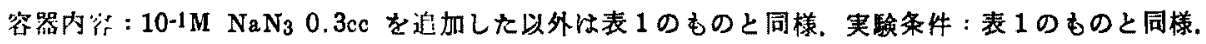

そ於てはその阻害はチオニン添加とよりやや 㤉復するようであつたが，Staph，aureus（寺 島）に於ては全く恢復しなかつた。

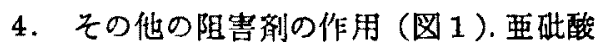
ソータは $10^{-2} \sim 10^{-3} \mathrm{M}$ の漠度に於て強くクル タミン酸呼吸を阻害した８・ヒドロオキンキ

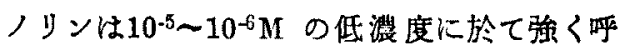
吸を陮害したが，その作用は Staph. aureus
（寺島）飞対してょり強く認められた，2，4シニーロフェノールす $10^{-2} \sim 10^{-3} \mathrm{M}$ K於て強 く呼吸を阻害した。

\section{第二算 生菌の呼吸に対する諸㮔抗 生物質の作用}

因2 K見る如く，諸種抗生物質中オーレオ マインン $\left(10^{-3} \sim 10^{-4} \mathrm{M}\right)$ が最す強い呼吸阻 
因 1 フドウ球菌の呼吸対する諸種阻害剂の作用

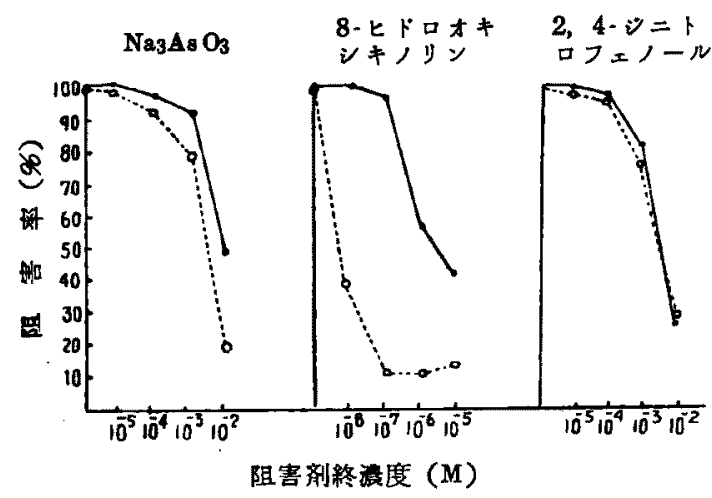

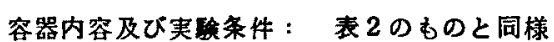

- - • staph. citreus, o…..ostaph. aureus（寺島）

図2 フドウ球菌の呼吸に対する諸種抗生物質の作用

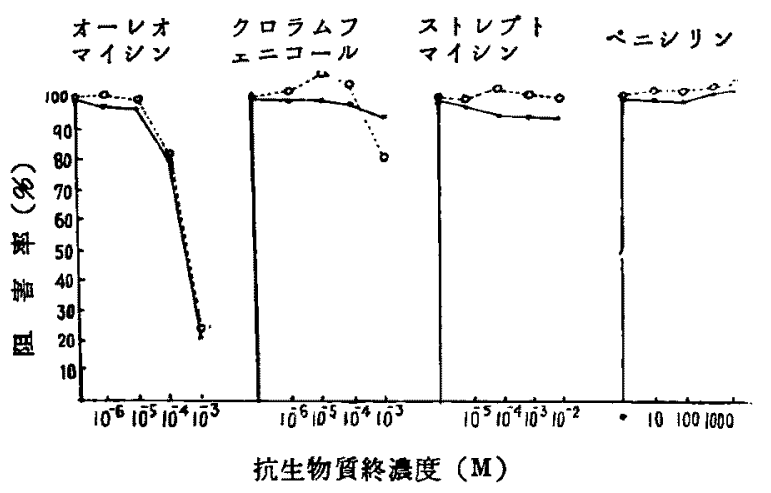

容器内容及び赛験条件・表 2 のものと同梯

-——ataph.citreus, O……ostaph.aureus（寺島）
2. 諸種阻害剂及び抗生物質 の作用(表 4).

生菌住対して強い呼吸阻害作 用を示したすの〉中，チオニン 亜砣酸ソーダ及び8-ヒドロオキ ンキノリンは無細胞抽出液のク ルタミン酸呼吸飞対しては全く

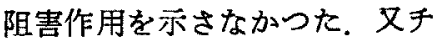
トクロム系作用すると考えら れるところの阻害剤の中，ンヤ ンカリ及び窒化ソータの作用は チオニンの添加汇より，ょく恢 復された．然しオクタノールル よる阻害はチオニン添加により 余り恢復されなかつた。

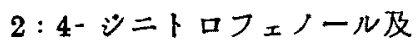
びオーレオマインンは生菌に対 すると同梯無細胞抽出液の呼吸 をる阻害した。これら無細胞抽 出液関して得られた結果は， Staph. citreus 及び aureus（寺 島）の画者に於てほぼ同様であ つた.

\section{総括及ひ考按}

クルタミン酸を基質とした場 合のフドウ球菌の呼吸は，矢
害作用を示した。 クロラムフェニコール $\left(10^{-3} \mathrm{M}\right)$ は極く軽度飞呼吸を阻害したが，ペ ニンリン及びストレプトマインンは認めるべ き呼吸阻害作用を示さなかつた。

第三简 無細胞抽出液飞よるクルタミ ン酸酸化に対する諸種阻害剂 及び抗生物質の作用

1. 無細胞抽出液の調撆法。フドウ球茵 の37 ${ }^{\circ} \mathrm{C}, 18$ 時間培養したすのを採取し，0〜 $3^{\circ}$ C r於て約 1 時間石英砂と磨砕し，湿菌聂 $300 \mathrm{mg}$ K対し $1 \mathrm{cc}$ の割合でM/50燐酸楥衝 液を加光， $0^{\circ} \mathrm{C}$ 於て，14,500G，40分閒遠 沈し，この上清を無細胞抽出液として使用し $t^{2)}$.
部2つが報告している様に，所謂呼吸と云う現 象として最も典型的な機序乃至機構によつて 行われる. 今これを模式的に表示すれば

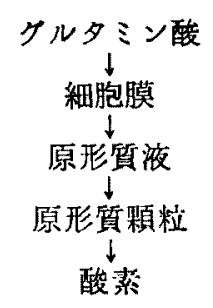

の如くなる。

前記諸種阻害剂及び抗生物質の呼吸に対す る作用について，この模式に往つて考按を縒 みたい.

キオニン，亜砒酸ソータ及び 8-ヒドロオ 
表 4 Staphylococcus citreus 無細胞抽出液によるグルタミン酸々化に 対さる諸種阻害剂及び抗生物質の作用

\begin{tabular}{|c|c|c|c|c|c|c|}
\hline \multirow{3}{*}{ 阻 害 剂 } & & 酸 & 消 謴 & 量 $\mu 1$ & \multirow{2}{*}{ 阻害踭名 } & \multirow{2}{*}{ 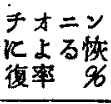 } \\
\hline & & 全 & 自己呼吸 & 補正量 & & \\
\hline & & 66 & 17 & 49 & 0 & \\
\hline $\mathrm{KCN}$ & $10^{-3} \mathbf{M}$ & 17 & 10 & 7 & 86 & \\
\hline 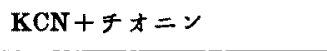 & & 68 & 22 & 46 & 6 & 80 \\
\hline $\mathrm{NaN}_{3}$ & $10-2 \mathrm{M}$ & 23 & 18 & 5 & 90 & \\
\hline $\mathrm{NaN}_{3}+$ チォニン & & 58 & 17 & 41 & 16 & 74 \\
\hline オクタノール & 飽和 & 21 & 17 & 4 & 92 & \\
\hline オクタノール+チォニン & & 53 & 30 & 23 & 53 & 39 \\
\hline $\mathrm{N}_{8} \mathrm{~A}_{8} \mathrm{O}_{2}$ & $10-2 \mathrm{M}$ & 78 & 30 & 48 & 2 & \\
\hline 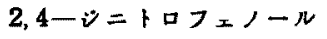 & $10^{-3} \mathrm{M}$ & 35 & 9 & 26 & 47 & \\
\hline 8一ヒドロオキレキノリン & $10-4 M$ & 66 & 17 & 49 & 0 & \\
\hline オーレォマインン & $2 \times 10^{-3} \mathrm{M}$ & 27 & 11 & 16 & 67 & \\
\hline ストレブトマカンン & $10-2 \mathrm{M}$ & 68 & 19 & 49 & 0 & \\
\hline$\dot{\sim}$ ニンリン & 4000単位/cc & 65 & 17 & 48 & 2 & \\
\hline
\end{tabular}

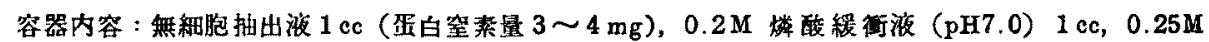
クルタミン酸 $0.6 \mathrm{cc}, 1 / 1000$ チオニン $0.3 \mathrm{cc}$ ，水を加えて全量 $3.0 \mathrm{cc}$ とする. 父相: 空気. $37.5^{\circ} \mathrm{C}$, 120 分.

キンキノリンは生箱の呼吸を強く阻害したが, 抽出液の呼吸を全く阻害しなかつた，Galed はクルタミン酸の Staph. aureus 内えの透過 は所謂 Energy-linked でありそこに $\mathrm{Mn}^{++}$ 或は $\mathrm{Mg}^{++}$が関与し，この機棈を 8-ヒドロオ キシキノリンは阻害するのであると報告して いる. 亜吪酸ソータについてはその機序は不 明であるが，これもクルタミン酸の細胞膜透 過を阻害するるのであると考えられる，又チ オニンを生菌に添加した場合菌の呼吸は阻害 され，阑はチオニンに染つていたが，その着 色は阼吸阴管の强いものに於て一般的に著し いのが垫められた。一方チオニンは焦細胞抽 出液のクルタミン酸呼吸を全く阻害しなかつ た，従つてチォニンが細胞膜に吸着される事

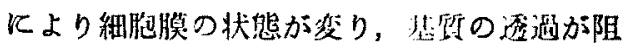
害されるものと灰えられる。文れオニンの生 菌の呼吸汇刘する阻害作用はケルタミン酸を 基質とした場合，クルコースを基䐝とした場 合よりる強加た。 この批より，クルタミ ン酸とグルコースの細胞膜透過機序が翼るこ
とが考光られる。

更に又,これらクルタミン酸の細胞膜透過 を阻害すると考えられるところのチオニン， 要砣酸ソーダ及び8-ヒドロオキンキノリン の何れによつても，Staph. aureus (寺島) が Staph. citreusよりるより強く阻害された。 この事より,クルタミン酸の透過機序, 従つて 勫胞膜の状態乃至機構は，同じフドウ球菌で もここれら両菌でかなり異る事が推測される。

ンヤンカリ及び窒化ソーダの呼吸阻害作用 は然細胞抽出液に於ては，テ才ニンの添加炕 より充分恢復された，従つてこれらのるの 阻害作用は，原形質顆粒化存在するところの チトクロム系化対して行われるすのと考えら れる。一方オクタノールの阻害作用はチオニ ン飞より余り恢復されなかつた，即ち従来報 告されている様に，ンヤン及びアシドとオク タノールでは同じチトクロム系に於てすその 阻害部位が異ることが考えられる576)。

2, 4ーシニトロフェノール及びオーレオマ

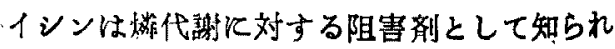


ているが，フドウ球菌に於てるその生菌及び 無細胞抽出液の両者の呼吸を阻害した，従つ てこれらのすのは呼吸に関聯した橉代謝即ち 酸化的燐酸化の機序を阻害するすのと考兄ら れる。以上を要䄪すれば次の栐になる。

キオニン，亜砒酸ソーダ及び8ーヒドロオ キシキノリンはクルルタン酸の細胞膜透過機 序を阻害し，それ以外のるのはチトクロム系 乃至呼吸関聯した橉代謝という原形質内の 真の呼吸機序を阻害すると考えられる。

無細胞抽出液でみられた現象がその㿿生菌 内に於ても行われていると考えるのは必ずし あ正しくはない，従つて前記の様に，はつき りとその呼吸阻害作用の機序をわりきること には多少とる危険性がある。然し細菌の示す 種々の生理現象の解明のため《阻害剂を使用 すると当つて，一忘その阻害剂の作用機序を 前記のようにすつきりとした形て於て理解し て括くことは細菌生理の研究上, 殊に細胞膜 の状態乃至その透過機序を研究し，理解する 上飞非常に重要なのではないかと考克られる。

\section{耛論}

1. チオン，互砒酸ソータ及び8ーヒドロオ

\section{文}

1）秋田：岡山医学会雑誌，69，549，1957。

2) Yabe, Y.: Japn. J. Microbiol. 印刷中.

3）秋田，矢部：日本細菌学雜誌，11，172，1956.

4) Gale, E. F. : Biochem. J., 48, 286, 1951.
キンノリンはフドウ球菌生菌のグルタミン酸 呼吸を著しく阻害したが，無細胞抽出液のも のは全く阻害しなかつた．又これらのるのは Staphylococcus aureus（寺島）の呼吸を Staphylococcus citreus のるのよりるより強く 阻害した。

2. 生菌に於ては, ンヤンカリ及び窒化ソ 一タによる呼吸阻害はチオニン添加により恢 復されなかつたが，無細胞抽出液に於てはチ オニンによりよく恢復された。

3、無細胞抽出夜飞於ては, オクタノール による呼吸阻害はチオニン添加により余り恢 復されなかつた。

4. 2，4ージニトロフェノールは生菌及び 無細胞抽出液の雨者のグルタミン酸呼吸を阻 害した。

5. 諸種抗生物質中，オーレオマインンの みがクルタミン醽呼吸を強く阻害した。

終始御瑟䉆なる御指莩と御校閲を睗つた恩即村上 夈敏授飞深甚の謝意を表し，併せて御協力下さつた 元井氏に心より感謝致します。

\section{献}

5) Keilin, D., Hartree, E. F.: Proc. roy. Soc., 127, 167, 1939.

6) Stephenson, M.: Bacterial Metabolism, 3rd Ed., 21, 1949. 


\title{
Action of Various Inhibitors and Antibiotics on Glutamate-Respiration of Staphylococcus
}

\author{
By \\ Yoshiro Yabe \\ Kazuo Akita \\ Yoshimi Akita
}

Department of Microbiology, Okayama University Medical School

(Director: Professor Dr. Sakae Murakami)

The author studied the action of various inhibitors and antibiotics on the glutamaterespiration of staphylococci under the consideration of physiological structure of the cell. Staphylococcus citreus and aureus (Terashima) were used as the test organisms, and L-glutamic acid as the substrate. The results were as follows :

1) Thionine, sodium arsenite and 8-hydroxyquinoline inhibited the respiration of intact cells of staphylococci markedly, but did not inhibit that of cell-free extracts. The inhibitive action of these three sorts of inhibitors was stronger on Staph. aureus (Terashima) than on Staph. citreus.

2) In intact cells, the inhibition of respiration by potassium cyanide and sodium azide was not restored by addition of thionine. In cell-free extracts, however, the inhibition by these two sorts of inhibitors was well restored by thionine.

3) By addition of thionine, the inhibition of the respiration of cell-free extracts by octanole was not so well restored as that by cyanide or azide.

4) 2,4-Dinitrophenol inhibited the glntamate-respiration of both of the intact cells and cell-free extracts.

5) Of all the antibiotics tested, aureomycin was the only one which noticeably inhibited the glutamate-respiration of staphylococci. 